\title{
The influence of marine algae on iodine speciation in the coastal ocean
}

\author{
Mary W. Carrano ${ }^{1}$, Kyoko Yarimizu ${ }^{1}$, Jennifer L. Gonzales ${ }^{1}$, Ricardo Cruz-López ${ }^{1}$, \\ Matthew S. Edwards' ${ }^{2}$, Teresa M. Tymon ${ }^{1}$, Frithjof C. Küpper ${ }^{3}$ and Carl J. Carrano ${ }^{1, *}$ \\ ${ }^{1}$ Department of Chemistry and Biochemistry, San Diego State University, San Diego, CA 92182-1030, USA \\ ${ }^{2}$ Department of Biology, San Diego State University, San Diego, CA 92182-1030, USA \\ ${ }^{3}$ School of Biological Sciences, University of Aberdeen, Cruickshank Building, St Machar Drive, Aberdeen AB24 3UU, \\ Scotland, UK
}

Iodine exists as a trace element in seawater, with total iodine being generally constant at about 0.45-0.55 $\mu \mathrm{M}$. Almost all of this iodine occurs in two main forms: iodate and iodide. Iodate is the thermodynamically stable form under normal seawater conditions, and thus should be the only iodine-containing species in the water column. However, iodate concentrations are found to vary considerably, being generally greater at depth and lower at the surface, while iodide concentrations follow the reverse pattern, being anomalously accumulated in the euphotic zone and decreasing with depth. The fact that iodide concentrations follow a depth dependence corresponding to the euphotic zone suggests that biological activity is the source of the reduced iodine. Nonetheless, the nature and source of iodate reduction activity remains controversial. Here, using a combination of field and laboratory studies, we examine some of the questions raised in our and other previous studies, and seek further correlations between changes in iodine speciation and the presence of marine macro- and microalgae. The present results indicate that microalgal growth per se does not seem to be responsible for the reduction of iodate to iodide. However, there is some support for the hypothesis that iodate reduction can occur due to release of cellular reducing agents that accompany cell senescence during phytoplankton bloom declines. In addition, support is given to the concept that macroalgal species such as giant kelp (Macrocystis pyrifera) can take up both iodide and iodate from seawater (albeit on a slower time scale). We propose a mechanism whereby iodate is reduced to iodide at the cell surface by cell surface reductases and is taken up directly as such without reentering the bulk solution.

Key Words: Ectocarpus; iodate; iodide; iodine speciation; Lingulodinium; Macrocystis; phytoplankton

\section{INTRODUCTION}

Marine production of organic halogenated compounds has been proposed as an important link between ocean biology, atmospheric composition, and climate (Carpenter 2003, Quack et al. 2004, Salawitch et al. 2005, Saiz-Lopez et al. 2012). For example, iodine atoms released from the photooxidation of organic and inorganic halogenated compounds enter catalytic ozone destruction cycles and can indirectly lead to a reduction in tropospheric ozone production by suppressing levels of nitrogen oxides (Davis et al. 1996). In addition to its widespread, global ef-
(†) This is an Open Access article distributed under the terms of the Creative Commons Attribution Non-Commercial License (http://creativecommons.org/licenses/by-nc/3.0/) which permits unrestricted non-commercial use, distribution, and reproduction in any medium, provided the original work is properly cited.
Received March 12, 2020, Accepted May 25, 2020

* Corresponding Author

E-mail: ccarrano@mail.sdsu.edu

Tel: +1-619-594-1617, Fax: +1-619-594-4634 
fects on climate, reactive iodine in particular may impact local and regional patterns of cloud formation in coastal areas via nucleation and growth of particles involving iodine oxides (O'Dowd et al. 2002, Saiz-Lopez et al. 2006, Küpper et al. 2008).

Iodine exists as a trace element in seawater due to its lithophilic nature and is heavily concentrated around subduction zones and volcanic arcs. The long residence time of iodine in seawater, $\sim 300$ k.y., suggests that iodine should have a uniform distribution due to limited biogeochemical cycling (Hardisty et al. 2014). Indeed, total iodine is generally constant in seawater at about 0.45 $0.55 \mu \mathrm{M}$ (Chance et al. 2014). All of this iodine occurs in two main forms: iodate, $\mathrm{IO}_{3}{ }^{-}$, and iodide, $\mathrm{I}^{-}$(with variable small quantities of organoiodine species). Iodate exhibits median concentrations of approximately $423 \mathrm{nM}$ and iodide $77 \mathrm{nM}$ (Chance et al. 2014). Iodate is the thermodynamically stable form under normal seawater conditions and thus should be the only iodine containing species in the water column. However, iodate concentrations are found to vary from $<0.1$ to $0.45 \mu \mathrm{M}$, and are generally greater at depth, but lower at the surface and in hypoxic environments near benthic sediments. Concentrations of iodide (a reduced form of iodine) on the other hand, follow the reverse pattern being anomalously accumulated in the euphotic zone and decreasing with depth, i.e., they exhibit an "anti-nutrient" like profile (Campos et al. 1996, 1999).

The fact that iodide concentrations follow a depth dependence corresponding to the euphotic zone suggests that biological activity is the source of the reduced iodine. Once reduced, the kinetics of reoxidation of iodide back to iodate are known to be extremely slow, allowing the buildup of iodide in the seawater (Luther et al. 1995). Despite an extensive literature, the nature and source of iodate reduction activity remains controversial, with macroalgae, phytoplankton, bacteria etc. all having been suggested to be involved along with a number of abiotic processes (Butler et al. 1981, Farrenkopf et al. 1997, Wong et al. 2002, Truesdale et al. 2003, Truesdale 2008, Chance et al. 2009). One of the most recent hypotheses put forward to explain the many disparate past observations suggests that the transformation from iodate to iodide is driven by cell senescence of marine phytoplankton. Here, reduction of iodate occurs not through active cellular metabolism of iodate, but rather via leakage of sulfur-containing reducing agents such as glutathione, cysteine etc. accompanying marine phytoplankton cell senescence (Bluhm et al. 2010).

As the coast is approached a number of studies have found that the concentration of iodate diminishes while that of iodide increases, suggesting that coastal waters are particularly effective points of iodate reduction (Chance et al. 2014). Many coastal ecosystems are dominated by macroalgae that have been identified as major contributors to the biogeochemical flux of iodine and iodocarbons to the atmosphere. It is therefore reasonable to suppose that these organisms could also influence iodine speciation in the coastal zone. In particular, since brown algae such as the giant kelp Macrocystis pyrifera, which produce dense kelp forests, are known to have highly evolved halogen metabolisms (Küpper and Carrano 2019) and high biological productivity rates, we hypothesize that they could influence iodine speciation in the coastal regime. Thus, in a previous study we examined iodide and iodate concentrations in seawater in and around a giant kelp forest near Pt. Loma, CA, USA, and at a nearby site, Scripps Pier, where we examined the potential influences of marine micro- and macroalgae on iodine speciation (Gonzales et al. 2017).

The most surprising observation from the kelp forest studies was that while seawater iodide concentrations increased only slightly in and around the kelp forest in the summer, when the forest biomass was at its maximum, iodate decreased dramatically compared to a control site. The observation that iodate decreased far more than iodide increased suggested not only was iodine speciation being affected in and around kelp forests, but also that a considerable amount of the iodate was removed from the water column, rather than simply being reduced to iodide. The simplest hypothesis to account for this observation is that iodate is being actively taken up by Macrocystis or its associated kelp forest species. However, this would be unexpected, in that previous work on the stipitate kelp Laminaria digitata in the eastern North Atlantic showed that iodide was the only form of iodine that is taken up by the kelp (Küpper et al. 1998).

The Scripps Pier site was chosen to address the Bluhm hypothesis (Bluhm et al. 2010) that reduction of iodate occurs due to leakage of sulfur containing reducing agents that accompany marine phytoplankton cell senescence. Here we hoped to make use of intense nearshore algal blooms which are well-known to occur at this site. We proposed to monitor iodine speciation pre-bloom, during the bloom maximum, and post-bloom at this location, with the expectation that detectable increases in iodide concentrations post-bloom would be consistent with the cell senescence model. However, contrary to expectations, there were no phytoplankton blooms at Scripps Pier during any part of a field campaign we con- 
ducted in 2014-2015. Indeed, we found that by examining the SIO-Scripps Pier HAB monitoring report monthly, total phytoplankton abundance was unusually low and unchanged during the year, possibly due to low nutrient availability that resulted from a period of anomalously warm water and the strong El Niño Southern Oscillation that occurred between 2014-2016. Consequently, the Scripps Pier site ultimately served not as a testing site for the influence of phytoplankton activity on iodine speciation, but rather as a near ideal "non-biological" control site where values of iodate $(375 \pm 43 \mathrm{nM})$ and iodide (150 $\pm 11 \mathrm{nM}$ ) were essentially invariant.

Here, using a combination of field and laboratory studies we look to examine some of the questions raised in our and other previous studies, and seek to further understand correlations between changes in iodine speciation and the presence of marine macro- and microalgae.

\section{MATERIALS AND METHODS}

\section{Water sampling}

Baja California Pacific Ocean Cruise of 2017. As a secondary goal of a 4-day research cruise (Mar 23-26, 2017) in the Pacific Ocean along the coast to offshore, from Ensenada, Mexico to the United States border (Yarimizu et al. 2019) designed to measure the concentration of dissolved iron as well as the distribution of bacteria producing photoactive siderophores, we also measured concentrations of iodide. A total of 22 stations (Fig. 1) were sampled at two depths: at the surface and at the deep chlorophyll maximum (DCM). The DCM was detected with a SBE 19V2 SeaCAT Profiler CTD (Sea-Bird Scientific, Bellevue, WA, USA). Station locations were determined by real-time monitoring using a Sea Soar and Moving Vessel Profiler, and sampling depths were determined based on a pressure-triggered auto-fire module that was mounted on the rosette for the Niskin casts. Details of the general data collection and analysis were described in Yarimizu et al. (2017).

Scripps Pier. Surface seawater samples were collected from the Scripps Pier, La Jolla ( $32^{\circ} 53^{\prime} \mathrm{N},-117^{\circ} 15^{\prime} \mathrm{W}$ ), on an approximately monthly (or more frequently during apparent bloom events) basis from January 2017 to October 2018. The seawater was collected using cleaned bottles and the samples were immediately transferred to acid-washed polyethylene bottles, filtered through a 0.45 $\mu \mathrm{M}$ Millipore membrane (Billerica, MA, USA) to remove any biological components, and stored at $-20^{\circ} \mathrm{C}$ until

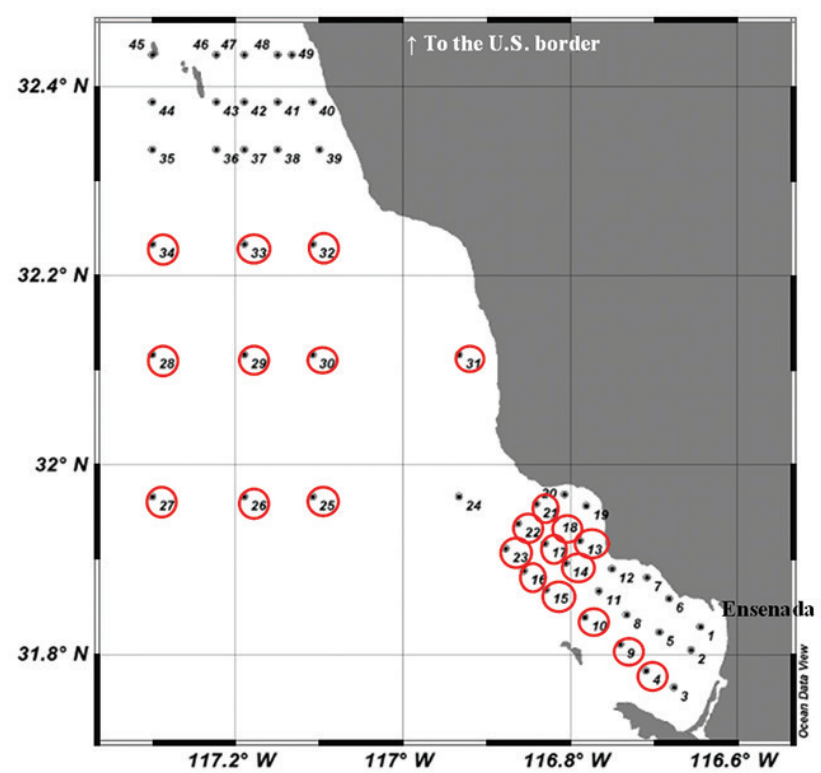

Fig. 1. Station map of cruise in the Pacific Ocean off the coast of Ensenada, Baja California, Mexico in March 2017.

analysis. Relative cell phytoplankton abundances were obtained from the Scripps Pier data site, http://www.sccoos.org/data/habs/index.php.

In situ sampling in the kelp forest. Experiments with macroalgal cultures were further supplemented by precision sampling of water by scuba divers in the kelp forest

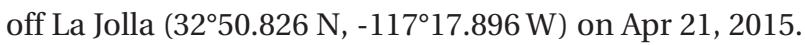
Specifically, three syringes $(50 \mathrm{~mL})$ each were filled with seawater collected from within the Macrocystis holdfast at $18 \mathrm{~m}$ depth, from within a dense pack of phylloids (i.e., fronds) at $15 \mathrm{~m}$, at the sea surface and at $10 \mathrm{~m}$ in a clearing in the kelp forest about $10 \mathrm{~m}$ distance from the kelp holdfast and phylloid sampling site. The latter served as a control.

\section{Effect of Lingulodinium polyedra on iodine spe- ciation}

Cultures of the bloom forming dinoflagellate Lingulodinium polyedra were maintained as previously described (Yarimizu et al. 2019). Cell counts at the start of the experiment averaged 3-7 $\times 10^{6}$ cells L $^{-1}$ and peaked at around $20 \times 10^{6}$ cells L $\mathrm{L}^{-1}$, values which are similar to those found during natural blooms of this organism (Moorthi et al. 2006). Iodine speciation was then measured at various times until bloom collapse caused either by heat treatment $\left(40^{\circ} \mathrm{C}\right.$ for $\left.1 \mathrm{~h}\right)$, exhaustion of nutrients, or infection of the culture with a virus which caused the decline and death of the dinoflagellate. 


\section{Effect of Ectocarpus siliculosus on iodine specia- tion}

The filamentous brown alga Ectocarpus siliculosus was grown at $20^{\circ} \mathrm{C}$ under a $12 \mathrm{~h}$ light / dark cycle. Scripps Pier seawater was filtered through 0.45 and $0.22 \mu \mathrm{m}$ Millipore filters, adjusted to $\mathrm{pH}$ 8.3, and autoclaved. Provasoli enrichment media (Starr and Zeikus 1993) was then added to the seawater after it cooled. Cultures were grown in Erlenmeyer flasks with approximately 450 to $600 \mathrm{~mL}$ of media. An inoculum of 8-17 mg squeezed-weight biomass per $\mathrm{mL}$ of media was used. At various times, from $\mathrm{t}=0$ to $t$ $=354 \mathrm{~h}$, aliquots of media were sterilely extracted, filtered through $0.22 \mu \mathrm{m}$ Millipore filters, and analyzed for iodine as below.

\section{lodine measurements}

Whether we measured iodate or iodide concentrations depended on both the matrix and the facilities available to us. For some samples, iodide concentrations were determined directly by cathodic stripping square wave voltammetry (CSSWV) as previously described (Luther et al. 1988, Gonzales et al. 2017). Iodate concentrations for these samples were determined indirectly from the difference between iodide and total reducible iodine determined by reducing all the iodine in the seawater samples into iodide using an ascorbic acid solution as previously described (Lucia and Campos 1997). For other samples, iodate concentrations were determined directly either by differential pulse voltammetry (DPV) according to Herring and Liss (1973) or as a modification of the spectrophotometic method of Truesdale (1978). Briefly, for DPV, $5 \mathrm{~mL}$ of sample was pipetted into a voltammetric cell to which $\mathrm{Na}_{2} \mathrm{SO}_{3}(1 \mathrm{M})$ was added to reduce oxygen. The sample was purged for several minutes with nitrogen to remove residual oxygen. System parameters were as follows: initial potential $(-650 \mathrm{mV})$, final potential $(-1,400$ $\mathrm{mV})$, step size $(4 \mathrm{mV})$, pulse width $(40 \mathrm{~ms})$, pulse period (200 ms), pulse amplitude (50 mV), and scan rate $(20 \mathrm{mV}$ $\mathrm{s}^{-1}$. Analysis was performed on a BASi controlled growth mercury electrode model MF-9058 interfaced with Epsilon software. A platinum wire served as the auxiliary electrode and an $\mathrm{Ag} / \mathrm{AgCl}$ electrode was used as the reference electrode. Iodate concentrations were determined (in triplicate) by the method of standard additions using known concentrations of potassium iodate. Total iodine concentrations were determined in duplicate samples by oxidizing all the iodine in the seawater samples into iodate using a dilute solution of hypochlorite solution as previously described (Takayanagi and Wong 1986). For these samples, iodide was then determined indirectly by taking the difference between total iodine and free iodate in samples as concentrations of non-oxidizable organoiodine species are expected to be very low. The spectrophotometric method of Truesdale (1978) relies on the reaction of iodate with excess iodide to form triiodide, which absorbs at $350 \mathrm{~nm}$. We modified this method to make it microscale by using $3 \mathrm{~mL}$ samples and measuring the OD at $350 \mathrm{~nm}$ on a NanoDrop spectrophotometer.

\section{Statistical analysis}

All statistical analyses were done using Systat ver. 12 (SAS Institute Inc., Cary, NC, USA) or as implemented in SigmaPlot 12.5 (Systat Software, Chicago, IL, USA). Prior to testing, all data were examined for normality by graphical interpretation of the residuals using probability plots, and for equal variances using Bartlett's test, which verified data were normally distributed and homoscedastic. A one-way ANOVA was then used to evaluate differences in iodide concentrations between the seawater collected from within the kelp holdfasts, in the middle of the kelp fronds, at the seawater surface, and in the water column within the kelp clearing. Following this, Tukey's honestly significant difference post hoc tests were used to assess differences in iodide concentrations between pairs of sampling locations.

\section{RESULTS}

\section{Ensenada cruise}

Water samples collected both at the surface and at the DCM showed that the average concentration of iodide at both depths was similar at $93 \pm 20 \mathrm{nM}$. Overall, the distribution of iodide was fairly uniform (Fig. 2) but with two "hot spots" (near stations 21, 22, 26, and 27), where the iodide concentration reached as high as $300 \mathrm{nM}$ and total iodine of $>650 \mathrm{nM}$. We initially considered these high values to be the result of some factor in the water that interfered with the CSSWV method used to measure iodide. However, reanalysis of these water samples using two totally different analytical procedures (DPV and spectrophotometry) continued to indicate highly elevated iodide and total iodine levels. Attempts to correlate iodide concentrations with various ocean chemistry parameters, Chl $a$ levels, and / or phytoplankton cell counts did not reveal any statistically significant relationships. Thus, 

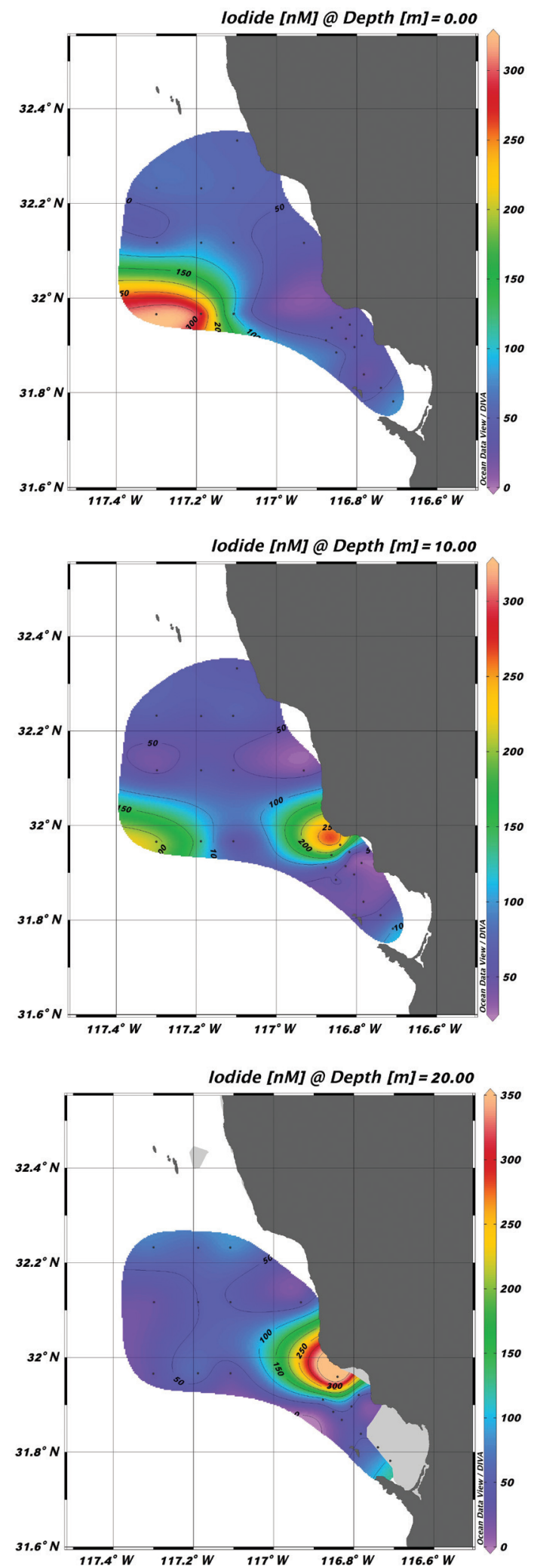

Fig. 2. Concentrations of iodide measured during a cruise in the Pacific Ocean off the coast of Ensenada, Baja California, Mexico in March 2017. Data plotted using Ocean Data View (Schlitzer, R., Ocean Data View, http://odv.awi.de, 2018). no obvious explanations for the "hot" spots of iodide concentration are evident at this time. Eliminating these high values as outliers, the highest concentrations of iodide found were in the 100-250 $\mathrm{nM}$ range, and the overall average dropped to $84 \mathrm{nM}$ at the surface and $69 \mathrm{nM}$ at the DCM, which are somewhat lower but still in the range of values (150 nM) found at Scripps Pier in 2015. Although we did not generally measure iodate concentrations for water samples obtained on this cruise, assuming an expected total iodine concentration between 400-500 nM would indicate that iodate concentrations would be on the order of 320-420 $\mathrm{nM}$.

\section{Effects of microalgae on iodine levels and spe- ciation}

Scripps Pier. In contrast to our 2015 study, where the iodate concentration at this site remained largely constant, the value of iodate measured during 2017-2018 varied considerably. Iodate values during this time period ranged from less than $200 \mathrm{nM}$ to almost $500 \mathrm{nM}$ with an average of 301 (75) nM (Fig. 3). This average iodate concentration is substantially less $(p=0.001)$ than the average of 375 (43) nM seen during 2015. For samples where the measured iodate concentration was below the mean we also measured iodide concentrations (where [iodide $]=[$ total iodine $]-$ [iodate $]$, assuming the quantity of any organoiodine species to be small). Importantly, low values for the concentration of iodate led to correspondingly higher values for the concentration of iodide, which suggested that the low values of iodate were not due to loss of iodine from the water column, but rather to a change in its speciation whereby iodate was converted into iodide, presumably due to reduction.

A closer inspection of Fig. 3 shows that while iodate concentrations in 2017-2018 were generally significantly lower than those measured in 2015, there were periods when the iodate concentration equalled or exceeded the 2015 values. Phytoplankton cell numbers measured on the same dates as the iodate measurements revealed that elevated iodate concentrations appeared to correlate (Pearson correlation $\mathrm{p}=0.029$ ) with high phytoplankton cell numbers such as was evident during a bloom of the Lingulodinium polyedra that occurred between May and June of 2018. Values of iodate then appeared to drop and be at their minima after the bloom declined.

Lingulodinium polyedra. In order to test the hypothesis that the release of reducing agents accompanying phytoplankton cell senescence might function to provide a mechanism for the increase in iodide concentra- 


\section{Scripps Pier 2017-2018}

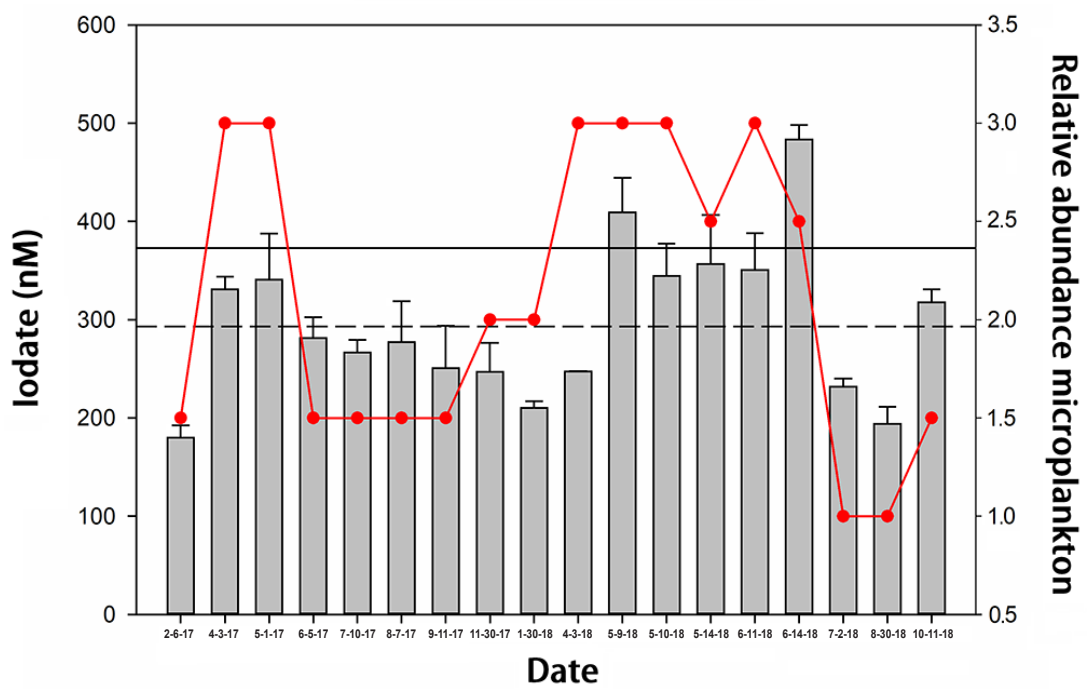

Fig. 3. Concentration of iodate at Scripps Pier over the time period Feb 6, 2017-Oct 11, 2018. The lower dotted horizontal line represents the mean of this data, the upper solid horizontal line represents the mean value of iodate measured in 2015 at this same site and the red plot the relative abundance of phytoplankton measured at the site taken from the SIO Pier HAB List (sio-pier-hab-list-I@sio.ucsd.edu) where 3 represents high abundance, 2 medium and 1 low.

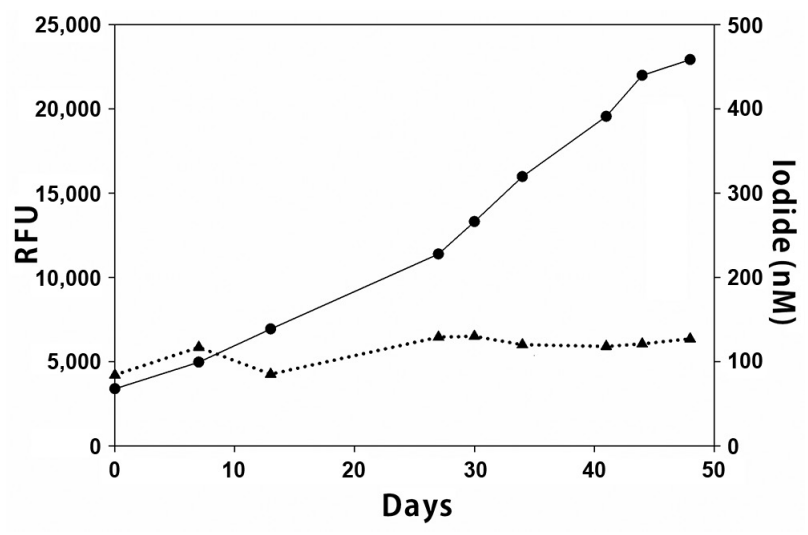

Fig. 4. Upper curve, growth (in relative fluorescence units [RFU]) of Lingulodinium polyedra as a function of time; lower curve, corresponding concentration of iodide.

tions in areas of high biological productivity, we used a laboratory model to study the effects of bloom dynamics on iodine speciation in culture. Starting media iodide concentrations of between 100-130 nM at time $\mathrm{t}=0 \mathrm{did}$ not change significantly while the Lingulodinium culture was healthy and growing (Fig. 4). However, as the culture began to decline, interferences presumably released from dead and decaying cells made reliable accurate measurements of either iodate or iodide problematic. In a few experiments iodide concentrations more than doubled to between 220-300 nM, while in the majority, there were no statistically significant changes. Thus, no definitive evi- dence either for or against the cell senescence hypothesis are obvious from these experiments.

\section{Effects of macroalgae on iodine levels and spe- ciation}

Ectocarpus. The general consensus has for a long time been that iodide is the only form of iodine that is taken up by brown macroalgae. However, some recent reports from both field and laboratory studies suggest that iodate may also be transported (Truesdale 2008, Gonzales et al. 2017). A perennial concern is the use in most previous studies of iodine uptake of employing plugs cut from field collected samples that had been removed from their natural environment for extended periods of time. There is some evidence that such samples may not represent "natural" behavior but are the results of abnormal stress due to the collection, holding and plugging of samples. In addition, uptake studies have generally been performed using seawater amended with unnaturally large $(\mu \mathrm{M})$ concentrations of iodine. We have therefore attempted to measure iodate uptake using Ectocarpus, which has advantages as a model brown alga for such studies in that it can be grown routinely in long term laboratory culture, unlike Macrocystis and Laminaria. Thus, we monitored both iodate and total iodine concentrations in cultures of Ectocarpus as a function of time starting at "normal" ambient concentrations of these species to determine if 


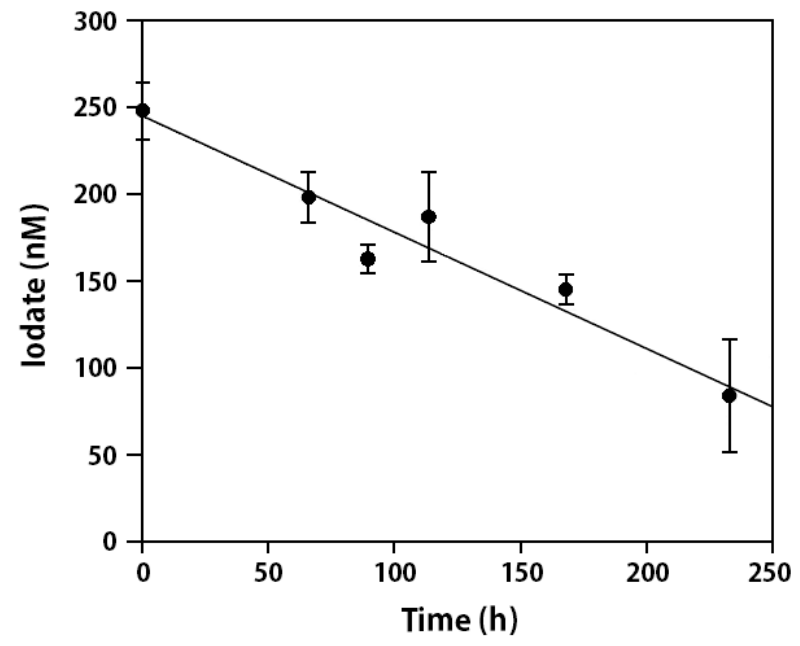

Fig. 5. A representative graph of change in concentration of iodate in the media during growth of Ectocarpus siliculosus over a two-week period. Solid line is the least squares fit to a linear decrease and error bars represent plus or minus the standard deviation from the mean of three technical replicates. The mean rate of decrease of ten biological replicates was $-0.09(0.03) \mathrm{nM} \mathrm{h}^{-1} \mathrm{~g}^{-1} \mathrm{FW}$.

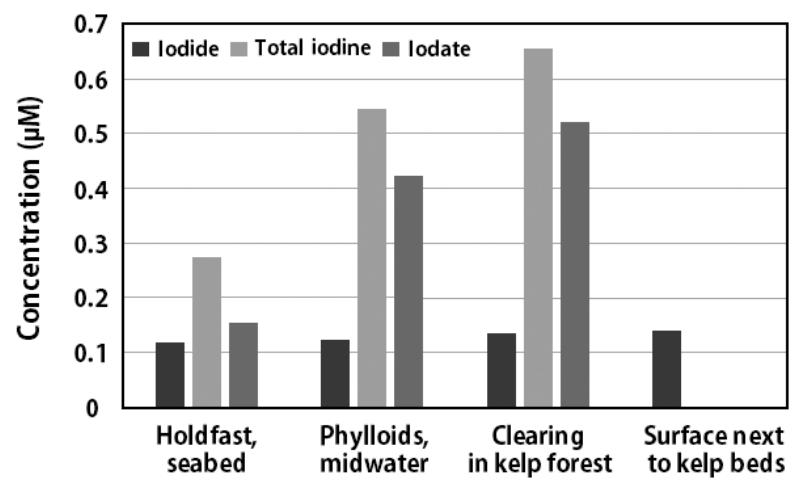

Fig. 6. Concentrations of total iodine, iodide and iodate in water samples collected by syringe in and around kelp beds (total iodine and iodate not measured for surface sample).

iodate is taken up or is converted to iodide. We initially sought to determine the time frame for any purported uptake of iodate by Ectocarpus, which showed that at ambient iodate concentrations (200-400 $\mathrm{nM}$ ) iodate uptake was unobservable over the $24 \mathrm{~h}$ time period commonly used for iodide uptake experiments, consistent with other studies. However, extending the exposure time to iodate for this relatively slow-growing organism from hours to days / weeks led to an apparent decrease in the iodate concentration in the media, as seen in Fig. 5. The rate of iodate decrease for 10 replicate cultures was roughly linear and gave a value of $-0.09(0.03) \mathrm{nM} \mathrm{h}^{-1} \mathrm{~g}^{-1}$ fresh weight. In order to determine whether iodate was actually being taken up or simply being converted to iodide via some reductive process, we measured total iodine and hence indirectly iodide (vide supra) at the last time point for each experiment, when iodate concentrations were at their minima. The lack of any corresponding increase in iodide when iodate was low suggested that iodate was actually being removed from the media rather than being converted to iodide.

In situ water sampling in the kelp forest. All samples collected within centimetres of the kelp showed a reduction in total iodine levels. Indeed, iodide concentrations varied significantly among the seawater collected from the holdfasts, within the kelp fronds, in the mid-water, and at the sea surface (ANOVA: $\mathrm{F}_{3,8}=10.104, \mathrm{p}=0.004$ ). Specially, iodide concentrations were significantly lower in the holdfasts than in the clearings or at the surface (Tukey's: $\mathrm{p}=0.024$ and $\mathrm{p}=0.006$, respectively), and tended to be lower, albeit not significantly, than in the fronds $(\mathrm{p}=$ 0.745). Likewise, iodide concentrations were significantly lower in the kelp fronds than at the surface (Tukey's: $0.022)$ and were marginally lower in the kelp fronds than in the clearings $(p=0.098)$. In contrast, iodide did not differ between the kelp clearings and at the sea surface $(p=$ 0.728). Nevertheless, concentrations of iodide decreased only slightly and stayed within the range typically observed in coastal waters. Thus, the overall reduction in total iodine appeared to be driven mostly by decreases in iodate (Fig. 6). It is important to note that the overall reduction in iodate was not mirrored by a corresponding increase in iodide (which also declined) indicating that the loss of iodate was due to an actual loss from the water column and not due to a change in speciation via reduction. The iodate loss was strongest for the samples collected within the haptera of the holdfast, where total iodine levels where iodate levels were only one-third of that observed in controls.

\section{DISCUSSION}

Overall, it appears that under "normal" circumstances the concentration of iodate in southern California / northern Baja coastal waters is between $250-400 \mathrm{nM}$, with iodide concentrations between $50-150 \mathrm{nM}$ as determined both at Scripps Pier and the Baja cruise. These values are entirely in accord with other reports (Chance et al. 2014). By "normal" we refer to situations in which either biological activity (phytoplankton cell counts) were low (i.e., Scripps Pier during the 2014-2015 year, or the Baja Cruise of 2017), or where phytoplankton cell counts 
were high but were actively growing during bloom initiation or maxima (i.e., as seen in the Scripps Pier data for 2017-2018). We base this latter assumption on the fact that actively growing cultures of Lingulodinium (the primary phytoplankton species found at Scripps Pier) do not appear to affect iodine speciation as demonstrated by our own laboratory experiments (Fig. 4).

However, it also appears that iodate concentrations decline and iodide concentrations increase during the weeks after a bloom collapse (Fig. 3). This pattern would be consistent with the hypothesis that it is not actively growing phytoplankton that lead to reduction of iodate to iodide, but rather the release of potential reducing agents during bloom decline or cell senescence. There are of course other possible explanations for the observed trends (seasonal upwelling etc.) and the cell senescence hypothesis could not be confirmed by our laboratory studies of Lingulodinium cultures due to interferences in the iodine assays in declining cultures.

Using the macroalga Ectocarpus, which can be grown reproducibly in the laboratory and has a halogen metabolism that has been recently studied (Küpper et al. 2018), we have also investigated the possibility that iodate as well as iodide can be taken up by brown macroalgae. We found that over a time period of days to weeks, iodate concentrations in media containing growing Ectocarpus cultures were found to fall significantly. Specifically, iodate concentrations were seen to drop from 250-350 nM at $\mathrm{t}=0$ to $100 \mathrm{nM}$ or less after two weeks. The fact that iodate decreased while there was no significant change in iodide indicates that bulk iodine speciation is not being affected but rather that a considerable amount of the iodate is being removed from the media. This is consistent with our earlier field study in the Pt. Loma kelp beds, which showed a statistically significant loss of iodate without a corresponding increase in iodide in the middle of the beds during the summer months, when biomass (Macrocystis) was at its maximum. The simplest hypothesis to account for these observations is that iodate itself is being actively taken up. However, a number of alternative theories to account for the loss of iodate without a concomitant increase in iodide exist. Indeed, a viable alternative is that iodate is reduced to iodide at the surface of macroalgal cells by cell surface reductases and then transported into these cells as iodide without reentering the bulk solution. Such NAD(P)H dependent cell surface reductases are known to exist in macroalgae (Cock et al. 2010, Böttger et al. 2012) and to have redox potentials capable of reducing iodate to iodide, albeit likely at a slow rate.
These conclusions were also supported by samples collected underwater by syringe in the Macrocystis kelp forest. Here, all samples collected within centimetres of kelp thalli showed reduced levels of total iodine, iodide and iodate, with iodate levels being by far the most affected. This again suggests an active depletion of iodate by Macrocystis from the water column, confirming our previously published results (Gonzales et al. 2017, Tymon et al. 2017). However, in comparison to our aforementioned study (Gonzales et al. 2017), the effect is much stronger for the data presented here. This is likely due to the fact that the samples were collected with syringes from the diffusion microenvironment above kelp thalli, whereas those in our previous study were much larger volume samples collected by Niskin bottles within the water column. Also, even though these samples were obtained within the kelp forest, they were collected metres away from the nearest kelp thalli, where mixing had inevitably occurred. Due to the syringe-based sampling methodology, the data presented here provide a perhaps more accurate reflection of the speciation and metabolic processes involving iodide and iodate on the kelp surface. It is remarkable that the water around the holdfast had the least iodine overall, with most of the loss coming from iodate. In our previous ICP work (Tymon et al. 2017) the holdfast itself was found to have the highest internal iodine concentration. This may suggest that the holdfast is taking up the most iodine and doing so as iodate and not iodide.

In conclusion, the present results indicate that microalgal growth / metabolism does not seem to be responsible for the reduction of iodate to iodide. However, there is some support for the hypothesis that iodate reduction can occur due to release of cellular reducing agents that accompany cell senescence during phytoplankton bloom declines. Further, support is given to the concept that the brown algae can take up not only iodide but iodate from seawater (albeit on a slower time scale). We propose a mechanism whereby iodate is reduced to iodide at the cell surface by cell surface reductases and is taken up directly as such without reentering the bulk solution.

\section{ACKNOWLEDGEMENTS}

This work was supported in part by grant CHE-1664657 from the National Science Foundation to CJC and FCK, the TOTAL Foundation (Paris) and the UK Natural Environment Research Council grants (NE/D521522/1, NE/ J023094/1, Oceans 2025 / WP 4.5) to FCK. We are also 
grateful for funding from the MASTS pooling initiative (The Marine Alliance for Science and Technology for Scotland). We thank Dr. M. L. Carter, SIO for help with collection of water samples at Scripps Pier, César O. Almeda-Jáuregui, CICESE for Ocean Data View plots and Dr. Avery Tatters, USC for the initial culture of Lingulodinium polyedra. A fellowship from the Hanse-Wissenschaftskolleg to CJC is also gratefully acknowledged.

\section{REFERENCES}

Bluhm, K., Croot, P., Wuttig, K. \& Lochte, K. 2010. Transformation of iodate to iodide in marine phytoplankton driven by cell senescence. Aquat. Biol. 11:1-15.

Böttger, L. H., Miller, E. P., Andresen, C., Matzanke, B. F., Küpper, F. C. \& Carrano, C. J. 2012. Atypical iron storage in marine brown algae: a multidisciplinary study of iron transport and storage in Ectocarpus siliculosus. J. Exp. Bot. 63:5663-5772.

Butler, E. C. V., Smith, J. D. \& Fisher, N. S. 1981. Influence of phytoplankton on iodine speciation in seawater. Limnol. Oceanogr. 26:382-386.

Campos, M. L. A. M., Farrenkopf, A. M., Jickells, T. D. \& Luther, G. W. 1996. A comparison of dissolved iodine cycling at the Bermuda Atlantic Time-series Station and Hawaii Ocean Time-series Station. Deep Sea Res. Part II Top. Stud. Oceanogr. 43:455-466.

Campos, M. L. A. M., Sanders, R. \& Jickells, T. 1999. The dissolved iodate and iodide distribution in the South Atlantic from the Weddell Sea to Brazil. Mar. Chem. 65:167175.

Carpenter, L. J. 2003. Iodine in the marine boundary layer. Chem. Rev. 103:4953-4962.

Chance, R., Baker, A. R., Carpenter, L. \& Jickells, T. D. 2014. The distribution of iodide at the sea surface. Environ. Sci. Process. Impacts 16:1841-1859.

Chance, R., Baker, A. R., Küpper, F. C., Hughes, C., Kloareg, B. \& Malin, G. 2009. Release and transformations of inorganic iodine by marine macroalgae. Estuar. Coast. Shelf Sci. 82:406-414.

Cock, J. M., Sterck, L., Rouzé, P., Scornet, D., Allen, A. E., Amoutzias, G., Anthouard, V., Artiguenave, F., Aury, J. -M., Badger, J. H., Beszteri, B., Billiau, K., Bonnet, E., Bothwell, J. H., Bowler, C., Boyen, C., Brownlee, C., Carrano, C. J., Charrier, B., Cho, G. Y., Coelho, S. M., Collén, J., Corre, E., Da Silva, C., Delage, L., Delaroque, N., Dittami, S. M., Doulbeau, S., Elias, M., Farnham, G., Gachon, C. M. M., Gschloessl, B., Heesch, S., Jabbari, K., Jubin, C., Kawai, H., Kimura, K., Kloareg, B., Küpper, F. C., Lang,
D., Le Bail, A., Leblanc, C., Lerouge, P., Lohr, M., Lopez, P. J., Martens, C., Maumus, F., Michel, G., Miranda-Saavedra, D., Morales, J., Moreau, H., Motomura, T., Nagasato, C., Napoli, C. A., Nelson, D. R., Nyvall-Collén, P., Peters, A. F., Pommier, C., Potin, P., Poulain, J., Quesneville, H., Read, B., Rensing, S. A., Ritter, A., Rousvoal, S., Samanta, M., Samson, G., Schroeder, D. C., Ségurens, B., Strittmatter, M., Tonon, T., Tregear, J. W., Valentin, K., von Dassow, P., Yamagishi, T., Van de Peer, Y. \& Wincker, P. 2010. The Ectocarpus genome and the independent evolution of multicellularity in the brown algae. Nature 465:617-621.

Davis, D., Crawford, J., Liu, S., McKeen, S., Bandy, A., Thornton, D., Rowland, F. \& Blake, D. 1996. Potential impact of iodine on tropospheric levels of ozone and other critical oxidants. J. Geophys. Res. 101:2135-2147.

Farrenkopf, A. M., Dollhopf, M. E., Chadhain, S. N., Luther, G. W. \& Nealson, K. H. 1997. Reduction of iodate in seawater during Arabian Sea shipboard incubations and in laboratory cultures of the marine bacterium Shewanella putrefaciens strain MR-4. Mar. Chem. 57:347-354.

Gonzales, J., Tymon, T., Küpper, F. C., Edwards, M. S. \& Carrano, C. J. 2017. The potential role of kelp forests on iodine speciation in coastal seawater. PLoS ONE 12:e0180755.

Hardisty, D. S., Lu, Z., Planavsky, N. J., Bekker, A., Philippot, P., Zhou, X. \& Lyons, T. W. 2014. An iodine record of Paleoproterozoic surface ocean oxygenation. Geology 42:619-622.

Herring, J. R. \& Liss, P. S. 1973. A new method for the determination of iodine species in seawater. Deep-Sea Res. Oceanogr. Abstr. 21:777-783.

Küpper, F. C., Carpenter, L. J., McFiggans, G. B., Palmer, C. J., Waite, T. J., Boneberg, E. -M., Woitsch, S., Weiller, M., Abela, R., Grolimund, D., Potin, P., Butler, A., Luther, G. W. 3rd., Kroneck, P. M. H., Meyer-Klaucke, W. \& Feiters, M. C. 2008. Iodide accumulation provides kelp with an inorganic antioxidant impacting atmospheric chemistry. Proc. Natl. Acad. Sci. U. S. A. 105:6954-6958.

Küpper, F. C. \& Carrano, C. J. 2019. Key aspects of the iodine metabolism of brown algae: a brief critical review. Metallomics 11:756-764.

Küpper, F. C., Miller, E. P., Andrews, S. J., Hughes, C., Carpenter, L. J., Meyer-Klaucke, W., Toyama, C., Muramatsu, Y., Feiters, M. C. \& Carrano, C. J. 2018. Emission of volatile halogenated compounds, speciation and localization of bromine and iodine in the brown algal genome model Ectocarpus siliculosus. J. Biol. Inorg. Chem. 23:11191128.

Küpper, F. C., Schweigert, N., Ar Gall, E., Legendre, J. -M., Vilter, H. \& Kloareg, B. 1998. Iodine uptake in Laminariales involves extracellular, haloperoxidase-mediated oxida- 
tion of iodide. Planta 207:163-171.

Lucia, M. \& Campos, A. M. 1997. New approach to evaluating dissolved iodine speciation in natural waters using cathodic stripping voltammetry and a storage study for preserving iodine species. Mar. Chem. 57:107-117.

Luther, G. W., Swartz, C. B. \& Ullman, W. J. 1988. Direct determination of iodide in seawater by cathodic stripping square wave voltammetry. Anal. Chem. 60:1721-1724.

Luther, G. W., Wu, J. \& Cullen, J. B. 1995. Redox chemistry of iodine in seawater: frontier molecular orbital theory considerations. In Huang, C. P., O’Melia, C. R. \& Morgan, J. J. (Eds.) Aquatic Chemistry. Vol. 244. American Chemical Society, Washington, DC, pp. 135-155.

Moorthi, S. D., Countway, P. D., Stauffer, B. A. \& Caron, D. A. 2006. Use of quantitative real-time PCR to investigate the dynamics of the red tide dinoflagellate Lingulodinium polyedrum. Microb. Ecol. 52:136-150.

O’Dowd, C. D., Jimenez, J. L., Bahreini, R., Flagan, R. C., Seinfeld, J. H., Hämeri, K., Pirjola, L., Kulmala, M., Jennings, S. G. \& Hoffmann, T. 2002. Marine aerosol formation from biogenic iodine emissions. Nature 417:632-636.

Quack, B., Atlas, E., Petrick, G., Stroud, V., Schauffler, S. \& Wallace, D. W. R. 2004. Oceanic bromoform sources for the tropical atmosphere. Geophys. Res. Lett. 31:L23S05.

Saiz-Lopez, A., Plane, J. M. C., Baker, A. R., Carpenter, L. J., von Glasow, R., Martin, J. C. G., McFiggans, G. \& Saunders, R. W. 2012. Atmospheric chemistry of iodine. Chem. Rev. 112:1773-1804.

Saiz-Lopez, A., Plane, J. M. C., McFiggans, G., Williams, P. I., Ball, S. M., Bitter, M., Jones, R. L., Hongwei, C. \& Hoffmann, T. 2006. Modelling molecular iodine emissions in a coastal marine environment: the link to new particle formation. Atmos. Chem. Phys. 6:883-895.

Salawitch, R. J., Weisenstein, D. K., Kovalenko, L. J., Sioris, C. E., Wennberg, P. O., Chance, K., Ko, M. K. W. \& McLinden, C. A. 2005. Sensitivity of ozone to bromine in the lower stratosphere. Geophys. Res. Lett. 32:L05811.

Starr, R. C. \& Zeikus, J. A. 1993. UTEX: the culture collection of algae at the University of Texas at Austin 1993 list of cultures. J. Phycol. 29(Suppl.):1-106.

Takayanagi, K. \& Wong, G. T. F. 1986. The oxidation of iodide to iodate for the polarographic determination of total iodine in natural waters. Talanta 33:451-454.

Truesdale, V. W. 1978. The automatic determination of iodate- and total-iodine in seawater. Mar. Chem. 6:253273.

Truesdale, V. W. 2008. The biogeochemical effect of seaweeds upon close-to natural concentrations of dissolved iodate and iodide in seawater: preliminary study with Laminaria digitata and Fucus serratus. Estuar. Coast. Shelf Sci. 78:155-165.

Truesdale, V. W., Kennedy, H., Agusti, S. \&Waite, T. J. 2003. On the relative constancy of iodate and total-iodine concentrations accompanying phytoplankton blooms initiated in mesocosm experiments in Antarctica. Limnol. Oceanogr. 48:1569-1574.

Tymon, T. M., Miller, E. P., Gonzalez, J. L., Raab, A., Küpper, F. C. \& Carrano, C. J. 2017. Some aspects of the iodine metabolism of the giant kelp Macrocystis pyrifera (Phaeophyta). J. Inorg. Biochem. 177:82-88.

Wong, G. T. F., Piumsomboon, A. U. \& Dunstan, W. M. 2002. The transformation of iodate to iodide in marine phytoplankton cultures. Mar. Ecol. Prog. Ser. 237:27-39.

Yarimizu, K., Cruz-López, R., Auerbach, H., Heimann, L., Schünemann, V. \& Carrano, C. J. 2017. Iron uptake and storage in the $\mathrm{HAB}$ dinoflagellate Lingulodinium polyedrum. BioMetals 30:945-953.

Yarimizu, K., Cruz-López, R., García-Mendoza, E., Edwards, M., Carter, M. L. \& Carrano, C. J. 2019. Distribution of dissolved iron and bacteria producing the photoactive siderophore, vibrioferrin, in waters off Southern California and Northern Baja. BioMetals 32:139-154. 